\title{
First report of two North American branchiobdellidans (Annelida: Clitellata) or crayfish worms on signal crayfish in Europe with a discussion of similar introductions into Japan
}

\author{
Stuart R. Gelder ${ }^{1 *}$, Jean-François Parpet ${ }^{2}$ and Francesco Quaglio ${ }^{3}$ \\ ${ }^{1}$ Department of Biology, University of Maine at Presque Isle, 181 Maine Street, Presque Isle, ME 04679-2888, USA \\ 2 Asconit Consultants, Agence Sud-Ouest Toulouse, Parc Technologique du Canal, 7 rue Hermes, 31520 Ramonville Saint-Agne, \\ France \\ 3 Dipartimento di Biomedicina Comparata ed Alimentazione, Viale dell‘Universita’ 16, 35020 Legnaro (PD), Italy
}

Received 7 March 2012; Accepted 6 June 2012

\begin{abstract}
Two species of North American branchiobdellidans, Cambarincola gracilis Robinson, 1954 and Cambarincola okadai Yamaguchi, 1933, have been reported in Europe for the first time. These branchiobdellidans together with Xirogoniton victoriensis Gelder and Hall, 1990 were found on signal crayfish, Pacifastacus leniusculus (Dana, 1852), collected from the Lot and Tarn River drainages in southern France. Specimens of $X$. victoriensis were also reported on the same host in the Mayenne River drainage in northeastern France. Brief morphological descriptions of the three alien branchiobdellidan species are given. These introductions are briefly discussed and compared with similar alien ectosymbiotic associations found in Japan.
\end{abstract}

Key words: Annelida / Cambarincola gracilis / C. okadai / crayfish

\section{Introduction}

Although it is not known when alien or non-indigenous crayfish species (NICS) from North America first arrived in Europe, it must have predated the outbreak of crayfish plague, Aphanomyces astaci Schikora, 1903, that appeared in the Po Valley, northern Italy in 1859 (Evans and Edgerton, 2002). As the pathogen proceeded to kill endemic or indigenous crayfish species (ICS) around the continent, gastronomic demands were met by importing crayfishes from the USA starting in the late 19th century and continuing until quite recently (Henttonen and Huner, 1999). While further imports of these crayfish for food have now declined or stopped, interest in a variety of alien crayfishes as pets in freshwater aquaria has risen. As was to be expected some of these species have escaped or been released into the wild resulting in new alien species being reported and increases in the distribution of others (Holdich et al., 2009). The concomitant introduction and spread of crayfish symbionts has recently taken on increased importance as veterinary health authorities attempt to control various introduced pathogens (Vogt, 1999; Evans and Edgerton, 2002); however, non-pathogenic organisms, in particular annelid branchiobdellidans

\footnotetext{
*Corresponding author: stuart.gelder@umpi .edu
}

or crayfish worms (Gelder, 2006; Govedich et al., 2010), continue to receive only passing interest. These are small, leech-like ectosymbionts that live primarily on Holarctic freshwater crayfishes (Gelder, 1999).

To understand the complexities raised by the current study, it is necessary to review briefly the commercial history of signal crayfish in Europe and particularly in France. Originally they consisted of three species, Pacifastacus leniusculus (Dana, 1852) and Pacifastacus trowbridgii (Stimpson, 1857) ranging from southern British Columbia, Canada, through western Washington and Oregon, USA, and Pacifastacus klamathensis (Stimpson, 1857) in southwestern Oregon and northern California (Riegel, 1959). However, their morphological differences are so small that they were reduced to subspecies rank, P. l. leniusculus, P. l. trowbridgii and P. l. klamathensis. Through subsequent commercial and sport fishing introductions throughout the Pacific Northwest, USA, and successful inter-breeding, it is often impossible to recognize individual subspecies and so they are now referred to as P. leniusculus (Lewis, 2002). Lake Tahoe in California and Nevada, USA, was stocked in about 1895 with $P$. leniusculus from the Klamath River. More were added in 1909, probably from Oregon coastal streams, and a third infusion occurred in 1916 from unreported sources (Abrahamsson and Goldman, 1970). These were not the 
Table 1. Collection sites and numbers of alien Pacifastacus leniusculus with their branchiobdellidan species and total numbers from each site. $C .=$ Cambarincola, $X .=$ Xironogiton.

\begin{tabular}{|c|c|c|c|c|c|c|c|c|}
\hline Site no. & Date & Site name & Department & Rivers & $\begin{array}{l}\text { Latitude/longitude } \\
\text { (degrees) }\end{array}$ & \multicolumn{2}{|c|}{$\begin{array}{l}\text { Worm species } \\
\text { and No. }\end{array}$} & $\begin{array}{l}\text { Host } \\
\text { No. }\end{array}$ \\
\hline \multicolumn{9}{|c|}{ Tarn drainage: } \\
\hline \multirow[t]{2}{*}{1} & $13 / 09 / 11$ & Salvetat sur Agout & Hérault & Agout & N43.606684 E2.698347 & C. gracilis & 2 & \\
\hline & & & & & & $\begin{array}{l}\text { C. okadai } \\
\text { X. victoriensis }\end{array}$ & $\begin{array}{l}1 \\
3\end{array}$ & 1 \\
\hline \multirow[t]{2}{*}{2} & $14 / 09 / 11$ & Lacaune & Tarn & Caunaise & N43.702322 E2.764630 & C. okadai & 12 & 4 \\
\hline & & & & & & $X$. victoriensis & 6 & \\
\hline 3 & $01 / 08 / 11$ & Brusque & Aveyron & Dourdou & N43.789027 E2.938024 & $X$. victoriensis & 32 & 1 \\
\hline 4 & $21 / 09 / 11$ & Curvalle & Tarn & Rance & N43.926207 E2.544494 & $X$. victoriensis & 30 & 3 \\
\hline 5 & $01 / 08 / 11$ & Brousse le Château & Aveyron & Alrance & N43.996508 E2.628392 & C. okadai & 1 & 3 \\
\hline 6 & $02 / 08 / 11$ & Alrance & Aveyron & Alrance & N44.127860 E2.677678 & $X$. victoriensis & 1 & 2 \\
\hline 7 & $29 / 07 / 11$ & Saint Beauzély & Aveyron & Muze & N44.172432 E2.965483 & $X$. victoriensis & 12 & 2 \\
\hline \multicolumn{9}{|c|}{ Lot drainage: } \\
\hline 8 & $20 / 07 / 11$ & Balsièges & Lozère & Lot & N44.503892 E3.460192 & X. victoriensis & 9 & 1 \\
\hline 9 & $17 / 08 / 10$ & St Félix de Lunel & Aveyron & Rau de Servan & N44.551966 E2.552527 & $X$. victoriensis & 4 & 4 \\
\hline 10 & $18 / 08 / 10$ & Nauviale & Aveyron & Créneau & N44.490380 E2.448379 & $X$. victoriensis & 12 & 2 \\
\hline \multicolumn{9}{|c|}{ Mayenne drainage: } \\
\hline 11 & $24 / 06 / 11$ & Heusse & Orne & Rau de longueves & N48.506092 W0.856354 & $X$. victoriensis & 1 & 1 \\
\hline
\end{tabular}

last introductions into Lake Tahoe, and other lakes and rivers in the region also received similar stockings. Fortunately Perry C. Holt examined crayfish collected from Lake Tahoe in 1964 and these were found to carry two branchiobdellidans, Xironogiton victoriensis Gelder and Hall, 1990 and Sathodrilus attenuatus Holt, 1981 (Gelder, 2005). Given the level of human transportation of crayfish in the Pacific Northwest, any chance of identifying the endemic distributions of the 15 branchiobdellidan species reported on P. leniusculus (Gelder et al., 2002; Gelder, 2004) would be almost impossible. Therefore these exported crayfish can be expected to carry any of the branchiobdellidans listed in Gelder (2004).

An experimental aquaculture project in 1959 introduced P. leniusculus from the Sacramento area, California, USA, into Sweden (Lewis, 2002; Holdich et al., 2009). Following this successful trial, additional stocks were imported from Lake Tahoe and released into numerous Swedish lakes. Similarly, stocks from Lakes Tahoe and nearby Hennessy, California, were also introduced into Finnish Lakes between 1967 and 1969 (Westman, 1973). Commercial success in rearing these crayfish and decreasing populations of European crayfishes led to Swedish-reared signal crayfish being transported to many other European countries. However, some countries obtained their stocks directly, whether legally or illegally, from sources other than Lake Tahoe in the Pacific Northwest (Holdich et al., 2009). The first report of an alien North American branchiobdellidan on P. leniusculus in Europe came shortly after their Swedish introduction when Franzén (1962) identified Xironogiton instabilis (Moore, 1894), subsequently renamed $X$. victoriensis. Populations of $X$. victoriensis flourished along with their hosts, resulting in both being introduced into various European countries (Gelder, 1999). Subsequent reports show that $X$. victoriensis is more widely distributed than thought with recent sightings in the
Italian Tyrol (Quaglio et al., 2001; Oberkofler et al., 2002), Manzanas, Zamora and Ebro rivers and tributaries, eastern Spain (Rosa Cubo E., unpublished data), and Rivers Lot (Laurent, 2007) and Dourbie in southern France (Subchev, 2008). Although $X$. victoriensis has remained the only alien species recognized from $P$. leniusculus on the continent, Kirjavainen and Westman (1999) raised the possibility that a cambarincolid had been seen in Finland when they reported, "either Xironogiton [victoriensis] instabilius Moore or Cambarincola sp., both of which were found in [on] signal crayfish imported from California in 1967-1969".

As our paper is focused on France, the first importations of $P$. leniusculus came from Sweden and they were released into northern and eastern regions of the country in 1972. Additional stocks came directly into central France from Lakes Tahoe and Donner, California, USA, in 1974 (Arrignon et al., 1999) and these were followed by illegal introductions directly from Oregon, USA (Holdich et al., 2009). From these populations we report an expanded distribution of $X$. victoriensis in France, and the first records of two Cambarincola species on P. leniusculus in Europe. Brief morphological descriptions of the three species are presented for ease of identification by European researchers, and these alien branchiobdellidan introductions are compared with a similar situation in Japan.

\section{Material and methods}

Pacifastacus leniusculus were collected as part of surface water quality monitoring studies for the Adour Garonne and Loire Bretagne Water Agencies in 2010 and 2011 by Asconit Consultants, Ramonville Saint-Agne, France. Sites were selected along rivers in the Tarn, Lot and Mayenne drainages, France (Table 1 and Fig. 9), with 12 samples taken from available habitats at each site. 

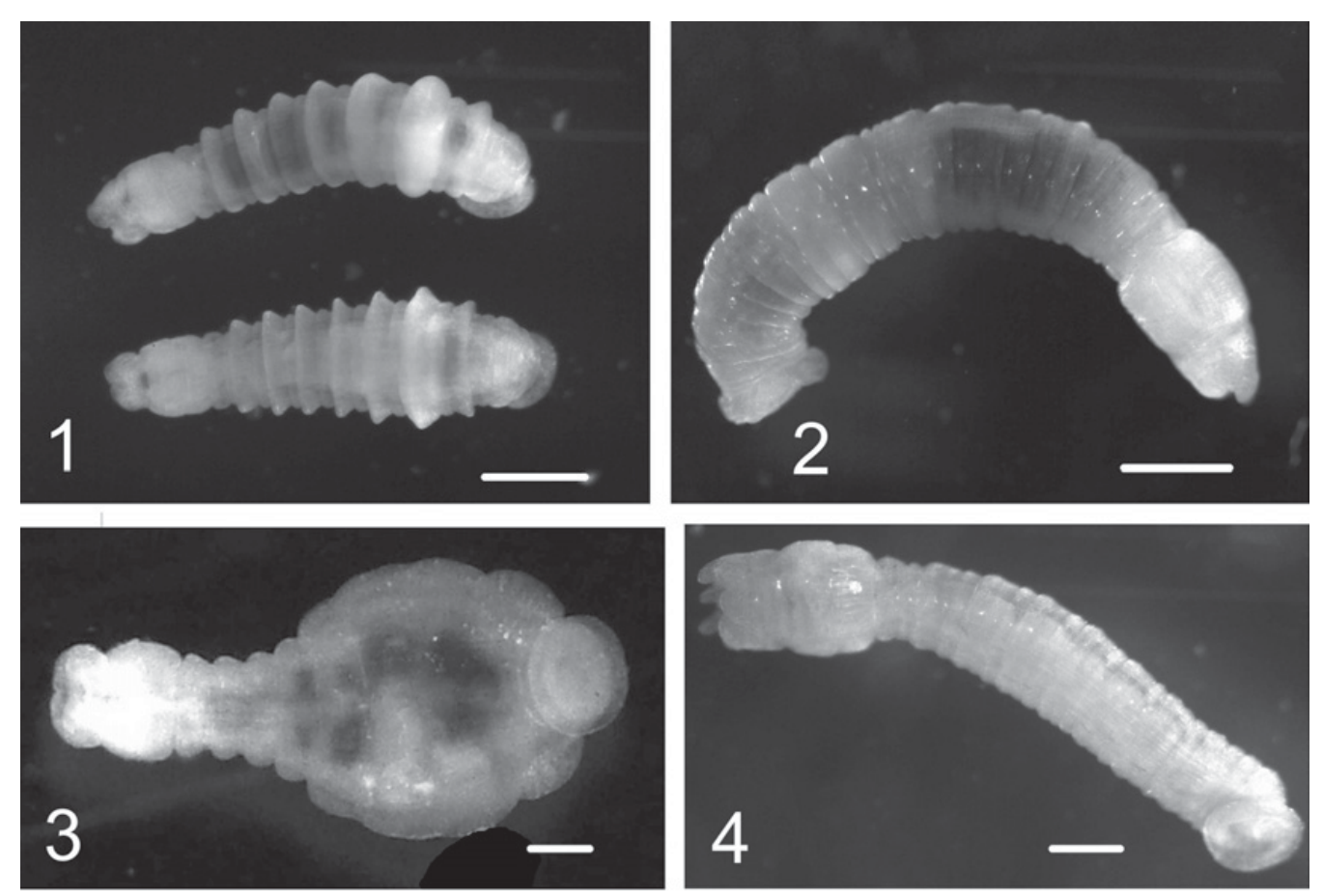

Figs. 1-4. Fig. 1. Cambarincola gracilis adults in lateral and dorsal aspects, bar $=0.5 \mathrm{~mm}$. Fig. 2. Cambarincola okadai adult in lateral aspect, bar $=1.0 \mathrm{~mm}$. Fig. 3. Xironogiton victoriensis adult in ventral aspect, bar $=0.4 \mathrm{~mm}$. Fig. 4. C. okadai juvenile in oblique ventral aspect, bar $=0.5 \mathrm{~mm}$.

Benthic fauna was sampled using a Surber sampler covering a $20 \mathrm{~cm}$ square substrate that was agitated by hand for about $1 \mathrm{~min}$ with displaced macrofauna and debris being carried by the current into a $0.5 \mathrm{~mm}$ mesh net. Captured organisms and sediments were transferred directly into bottles containing a $10 \%$ formalin solution, subsequently washed in running water in the laboratory and then any macrofauna observed under a stereomicroscope were removed and transferred into $70 \%$ ethanol for storage. This protocol is mandated by the Water Agencies. Crayfish were subjected to additional detailed examination to remove any branchiobdellidans remaining on the host and these were added to individuals recovered from the debris. Insufficient numbers of $P$. leniusculus were recovered by Surber sampling to provide branchiobdellidan population data, therefore this is a preliminary study to establish only the distribution of alien branchiobdellidan species in the areas surveyed.

Branchiobdellidans were divided into three groups with each group being characterized by having one of the following features: body racquet-shaped, peristomial tentacles, or transverse segmental ridges. Then up to 10 individuals from each group were selected and prepared for microscopical examination and identification. Specimens were dehydrated in a graded water: ethanol series from 70 to $100 \%$, then cleared in methyl salicylate (oil of wintergreen), infiltrated with Canada balsam, mounted on a microscope slide under a cover-glass (Govedich et al., 2010), and observed under a Nikon compound microscope using differential interference illumination (DIC). Photographs of unmounted branchiobdellidans were taken using a digital camera (Leica IC80 HD) mounted on a zoom stereomicroscope (Leica MZ9 5 ) under a cold light source illumination (Leica CLS 150X). Morphological terminology used in the brief descriptions follows that given in Govedich et al. (2010).

\section{Results}

Three species of North American branchiobdellidans were identified on $P$. leniusculus collected in France: Cambarincola gracilis Robinson, 1954 (Fig. 1), Cambarincola okadai Yamaguchi, 1933 (Figs. 2 and 4) and X. victoriensis Gelder and Hall, 1990 (Fig. 3), and this is the first record of the two Cambarincola species in Europe.

$X$. victoriensis is the most common branchiobdellidan found on P. leniusculus with 30 or more individuals on a host. Although the worms have a characteristic racquet shape (Fig. 3), preservation can sometimes cause them to appear more tubular. As a result, it is easy to overlook less frequently occurring cambarincolids even when they are present. However, C. gracilis often contracts upon preservation causing prominent transverse segmental ridges to appear (Fig. 1), and C. okadai is significantly longer (Fig. 2) than the other two species. Juvenile specimens are usually shorter than adults but the head size in some species (i.e., C. okadai) is almost the same as that in a fully grown individual (Figs. 2 and 4). Maturity is established when reproductive organs are observed in segments 5 and 6 , otherwise individuals are referred to as immature or juveniles. 

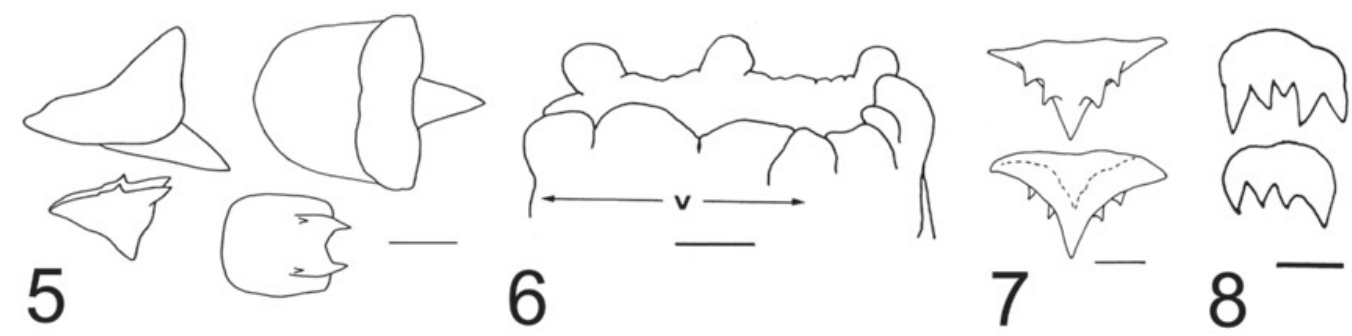

Figs. 5-8. Fig. 5. Cambarincola gracilis jaws in lateral aspect (left) and dorsal aspect (right) with teeth pointing posteriorly, bar $=25 \mu \mathrm{m}$; redrawn from Robinson (1954). Fig. 6. Cambarincola okadai with peristomium ("v", ventral lip) in ventral aspect, bar $=50 \mu \mathrm{m}$. Fig. 7. C. okadai ventral aspect of jaws (teeth pointing posteriorly), bar $=40 \mu \mathrm{m}$; Figures 6 and 7 redrawn and modified from Gelder and Ohtaka (2000). Fig. 8. Xironogiton victoriensis dorsal aspect of jaws (teeth pointing posteriorly), bar $=20 \mu \mathrm{m}$; redrawn from Gelder and Hall (1990).

\section{Brief descriptions of the three exotic North American branchiobdellidans}

All three North American species have spermatozoa in body segments 5 and 6 , and can be easily distinguished from endemic European Branchiobdella which carry spermatozoa only in body segment 5 . Each alien species has a unique combination of morphological characters: body length and shape, peristomial lip appendages and jaw structure.

C. gracilis are rod-shaped, 1.3-4.5 mm long, usually with dorsal transverse ridges on body segments; these are frequently prominent following preservation. The dorsal peristomial lip has four small lobes which may be partially withdrawn during preservation. The triangular dorsal jaw is large (about $2.5 \times$ the ventral) with a large median tooth, and the rectangular ventral jaw has two pairs of lateral teeth, a small anterior pair and a larger posterior pair (Fig. 5).

C. okadai are rod-shaped, 3.4-7.0 mm long, possessing no body segment ridges. The peristomial dorsal lip has four distinct lobes, two pairs of lateral lobes and a ventral lip partitioned into four ill-defined lobes (Fig. 6). Both jaws are similar sized, triangular, each with a large median tooth and two pairs of smaller lateral teeth (Fig. 7).

$X$. victoriensis are racquet-shaped and $1.8-2.8 \mathrm{~mm}$ long. Peristomial dorsal lip has four slight lobes in life, but usually appears smooth when preserved while lateral lobes are absent and the ventral lip has a slight median cleft. Jaws are similar sized, rounded rectangular, with irregular and randomly arranged teeth, usually five dorsal and four ventral (Fig. 8).

\section{Distribution of branchiobdellidans}

Branchiobdellidans were found at all 11 sites sampled in the upper Garonne and eastern Loire basins in southern and northwest France, respectively (Table 1 and Fig. 9, rectangles in inset); however, the ectosymbionts were not found on every signal crayfish collected. Each site supported populations of $X$. victoriensis except for site 5 (Fig. 9), where the three crayfish examined yielded only one $C$. okadai. This contrasted with site 1 where all three species were found on the single crayfish collected, and this was the only record of $C$. gracilis in the survey. As expected, $X$. victoriensis is the most wide spread and numerous (maximum of 32 individuals on a single host) of the three species detected in the Rivers Tarn, Lot and Mayenne (Table 1). Numbers of branchiobdellidans on each crayfish were not recorded and so ectosymbiont abundance and other population data are not available; however, being a preliminary study future monitoring will address these omissions.

\section{Discussion}

Prior to 1962, the only branchiobdellidans recorded in Europe were six endemic species of Branchiobdella. Subsequently, $X$. victoriensis on $P$. leniusculus (Franzén, 1962) and Cambarincola mesochoreus Hoffman, 1963 on Procambarus clarkii (Girard, 1852) (Gelder et al., 1994) were found in Europe. Both crayfishes had also been commercially introduced into Japan, $P$. clarkii having arrived in 1927 (Kawai and Kobayashi, 2006) and $P$. leniusculus, in the late 1920s (Kawai, 2002). The first and believed to be the only introduction of $P$. clarkii from New Orleans, Louisiana, USA, into Japan involved about 20 individuals being release into ponds in Kanagawa Prefecture (Kawai, 2002; Kawai and Kobayashi, 2011) where they reproduced rapidly and have since become widely distributed throughout the country. Kawai and Kobayashi $(2006,2011)$ examined P. clarkii from across Japan and did not find any branchiobdellidans. This supports the hypothesis that any branchiobdellidans leaving Louisiana in 1927 died in transit due to poor transportation conditions. In contrast, there is evidence that $P$. leniusculus were introduced into Japan on at least five separate occasions before imports were banned in 1930 (Kawai et al., 2004). Signal crayfish introduced into Hokkaido Island came from the Columbia River area in Oregon; however, the sources of other introductions from the Pacific Northwest, USA, are unknown (Kumakawa et al., 2011). The description of C. okadai on an "American crayfish" from Lake Chuzenji, central Honshu Island, Japan, by Yamaguchi (1933) raised some problems. The morphological description was incomplete; 


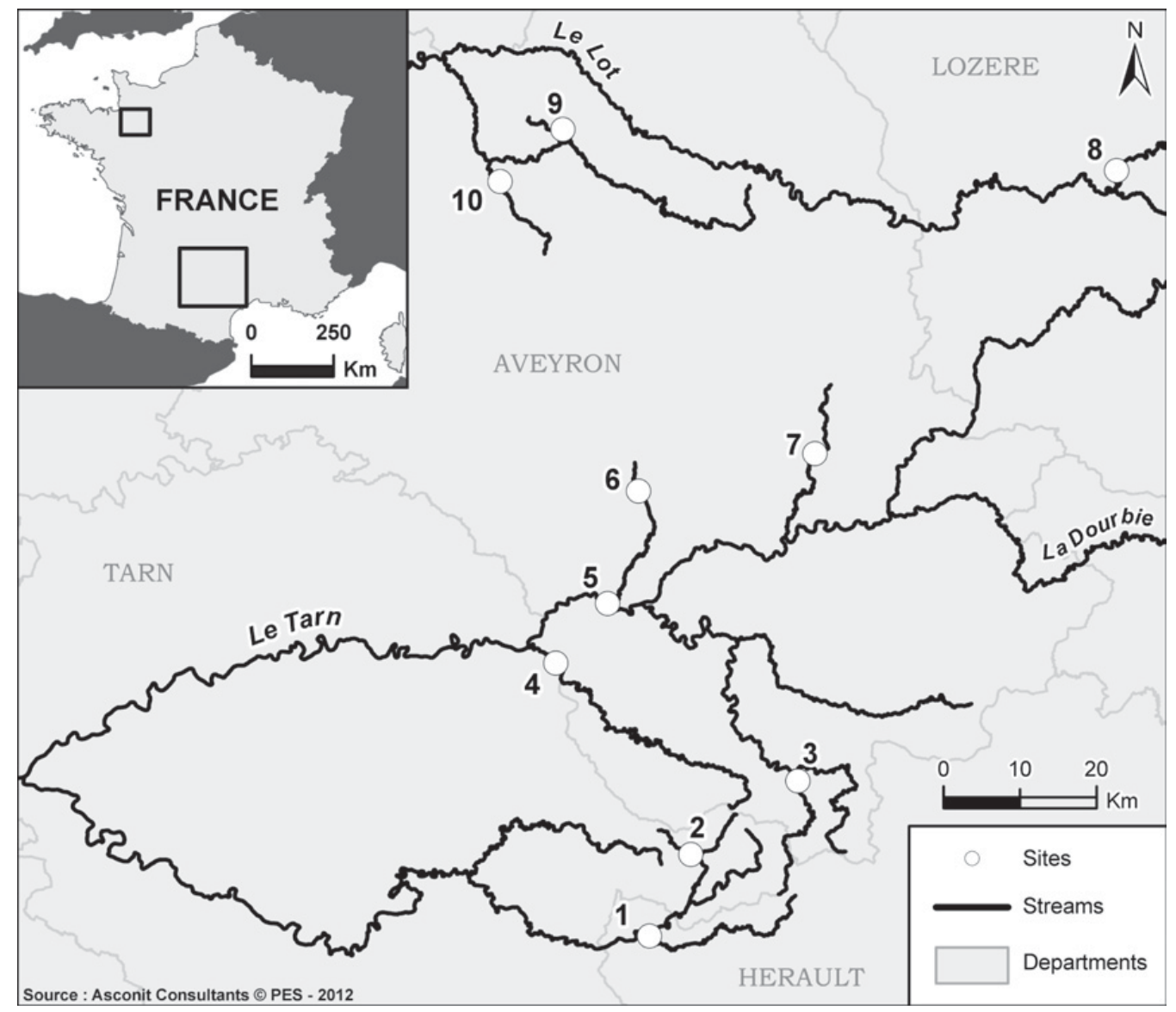

Fig. 9. The two study areas are rectangles in the map of France (inset), with collection locations indicated on Lot and Tarn rivers in the eastern Garonne Basin (sites 1-10) and Mayenne River in the western Loire Basin (site 11, inset).

he did not designate any type specimen, and no comparable branchiobdellidan was known in the Pacific Northwest. Following the rediscovery of Professor $\mathrm{H}$. Yamaguchi's slide collection, Gelder and Ohtaka (2000) were able to recognize his specimens, designate them as syntypes, make a detailed redescription of $C$. okadai and thus reduce the Northwestern USA species, Triannulata montana (Goodnight, 1940) to a junior synonym.

Given these reports of alien branchiobdellidans in Europe and East Asia, Gelder (2004) recognized the likelihood that other North American branchiobdellidans almost certainly had survived transportation and remained to be found. He listed all the branchiobdellidans reported on three North American crayfishes most frequently involved in commercial exports. This consisted of six branchiobdellidan species on $P$. clarkii, 15 on P. leniusculus and four on Orconectes limosus (Rafinesque, 1817). Shortly after, Ohtaka et al. (2005) found two additional branchiobdellidan species, Sathodrilus attenuatus Holt, 1981 in Hokkaido Island, and X. victoriensis in Nagano Prefecture, Honshu Island, Japan, both on $P$. leniusculus. Of the 15 branchiobdellidan species reported on $P$. leniusculus in the Pacific Northwest, USA, only seven are widely distributed. As $C$. okadai and $X$. victoriensis have been reported in both Europe and
Japan, only C. gracilis in Europe and S. attenuatus in Japan, this leaves Sathodrilus inversus (Ellis, 1919), Triannulata magna Goodnight, 1940 and Uglukodrilus hemophagus (Holt, 1977) as potential species to be discovered.

Branchiobdellidans occur as single or multi-species populations on a host and within a population of crayfish at a site, therefore not every individual will have branchiobdellidans or necessarily the same species composition (Govedich et al., 2010). This variability means not every crayfish batch that is exported will necessarily carry all the branchiobdellidan species present at the rearing source. Crayfish are more tolerant to temperature extremes, dehydration, and low oxygen tensions than branchiobdellidans resulting in their having lower survival rates following transportation, e.g., the absence of branchiobdellidans on $P$. clarkii across the Japanese Archipelago, and from P. leniusculus in Shiga Prefecture, central Honshu Island, Japan. Any one or a combination of these factors may account for the different species reported at our sites, and those of Laurent (2007) and Subchev (2008) in nearby locations.

Branchiobdellidans have been reported as being crayfish host species specific (McManus, 1960). While a few species may be, others exhibit a preference for certain 
hosts (Bishop, 1968; Gelder and Smith, 1987; Brown and Creed, 2004), but most branchiobdellidans are opportunistic regarding a crayfish host. Moreover, a small number of North American and East Asian branchiobdellidans have adopted non-crayfish hosts such as freshwater isopods, shrimps and crabs (Gelder, 1999; Gelder and Messick, 2006). Although a non-crayfish host-branchiobdellidan ectosymbiosis has not been reported in Europe, adoption of alien crayfish partners in Europe is known. $C$. mesochoreus on $P$. clarkii was discovered in northern Italy (Gelder et al., 1994) in the same area where Austropotamobius pallipes (Lereboullet, 1858) live carrying Branchiobdella parasita (Braun, 1805) and Branchiobdella pentodonta Whitman, 1882. Within 4 years B. parasita and B. pentodonta had replaced C. mesochoreus on P. clarkii at Torino (site 15), Italy (Gelder et al., 1999). A probable explanation is $P$. clarkii ate the endemic $A$. pallipes and the two endemic Branchiobdella species got transferred to a new host during contact. As B. parasita and $B$. pentodonta would recognize each other having been sympartic on $A$. pallipes, $C$. mesochoreus would appear alien and be vulnerable to predation by the larger $B$. parasita. Vogt (1999) found the same Branchiobdella species on Austropotamobius torrentium (Schrank, 1803) and on the alien $O$. limosus in the same stretch of Steinbach Creek, Hesse, Germany. Similarly, and with two additional species, Branchiobdella hexodonta Grüber, 1883 and Branchiobdella balcanica Moszyński, 1938, Duriš et al. (2006) recorded them on $O$. limosus in the northern Czech Republic. Although this North American crayfish species was introduced into Europe in the late 1890s and is quite widespread (Holdich et al., 2009), none of its endemic North American branchiobdellidans have ever being reported on the continent. Surprisingly no comparable adoption of alien or endemic branchiobdellidans and crayfishes has been reported in East Asia.

One ectosymbiosis not found in Europe or Japan is a shrimp-branchiobdellidan association; however, two examples are present in China where Caridinophilus unidens Liang, 1963 and Holtodrilus truncatus (Liang, 1963) both occur on freshwater shrimps (Liang, 1963). Recently $H$. truncatus was discovered on imported Chinese Neocaridina spp. (Niwa et al., 2005; Niwa and Ohtaka, 2006; Ohtaka et al., 2012) in central Honshu Island, Japan. As these shrimps are used for bait in freshwater sport fishing across Japan, escapes into local waters along with their branchiobdellidans has already started. At some point endemic Cambaroides japonicus (De Haan, 1841) and its branchiobdellidans will come into contact with alien $P$. leniusculus and Neocaridina spp. and their branchiobdellidans; what impact this will have on the ecology of these symbioses and diversity of Japanese freshwater species, remains to be seen. So far an endemic shrimp-branchiobdellidan association has not been reported in Europe, although the potential for one exists in the wild. However, when B. astaci were removed from $A$. pallipes and placed repeatedly on a troglodytic shrimp's (Troglocaris sp.) carapace, they reacted violently and refused to attach (Gelder, 1999). How common this response is for endemic branchiobdellidans on European shrimps remains to be determined.

Freshwater benthic monitoring programmes are likely to provide the first reports of further North American branchiobdellidans in Europe, but it is also important for monitors to be aware that particular branchiobdellidans can adopt available crayfish species and recognize the potential for other crustaceans to become hosts. Branchiobdellidan adoption of alien hosts shows a degree of behavioural and physiological tolerance not generally recognized by researchers. Investigations into these areas would not only advance our understanding of various ectosymbiotic associations but also help to predict the spread of introduced branchiobdellidans into the wider endemic fauna.

Acknowledgements. Our thanks to collection teams (Mathilde Bach, Marion Rossignol, Christelle Rougé, Aurélie Burgnies, Charline Blanco, Jennifer Martin, Julien Rimour, Frank David, Jérome Cayrou, David Bouché) and Philippe Espy for producing Figure 9 at Asconit Consultants, France, and Drs Andrea M. Gorman, University of Maine at Presque Isle, USA and T. Kawai, Wakkanai Fisheries Institute, Japan for manuscript suggestions. We also thank Jacky Durocher, Water Agency Loire Bretagne and Jean-Pierre Rebillard, Water Agency Adour Garonne, France, for permission to publish survey results and Dr. E. Rosa y Cubo, Estudios y Proyectos, S.L., Valladolid, Spain.

\section{References}

Abrahamsson S.A.A. and Goldman C.R., 1970. Distribution, density and production of the crayfish Pacifastacus leniusculus Dana inLake Tahoe, California-Nevada. Oikos, 21, 83-91.

Arrignon J.C.V., Gépard P., Kier A. and Laurent P.J., 1999. The situation in Belgium, France, and Luxembourg. In: Gherardi, F. and Holdich D.M. (eds.), Crayfish in Europe as Alien Species: How to Make the Best of a Bad Situation? A.A. Balkema, Rotterdam, Netherlands, 129-140.

Bishop J.E., 1968. An ecological study of the branchiobdellid commensals (Annelida-Branchiobdellidae) of some midwestern Ontario crayfishes. Can. J. Zool., 46, 835-843.

Brown B.L. and Creed R.P., 2004. Host preference by an aquatic ectosymbiotic annelid on 2 sympatric species of host crayfishes. J. North Am. Benthol. Soc., 23, 90-100.

Duriš Z., Horká I., Kristian J. and Kozák P., 2006. Some cases of macro-epibiosis on the invasive crayfish Orconectes limosus in the Czech Republic. Bull. Fr. Pêche Piscic., 380381, 1325-1337.

Evans L.H. and Edgerton B.F., 2002. Pathogens, parasites and commensals. In: Holdich D.M. (ed.), Biology of Freshwater Crayfish: Biology, Blackwell Science, London, UK, 377-438.

Franzén A., 1962. Notes on the morphology and histology of Xironogiton instabila (Moore, 1893) (Fam. branchiobdellidae) with special reference to the muscle cells. Zool. Bidr. Upps., 35, 369-383. 
Gelder S.R., 1999. Zoo geography of branchiobdellidans (Annelida) and temnocephalidans (Platyhelminthes) ectosymbiotic on freshwater crustaceans, and their reactions to one another in vitro. Hydrobiologia, 406, 21-31.

Gelder S.R., 2004. Endemic ectosymbiotic branchiobdellidans (Annelida: Clitellata) reported on three "export" species of North American crayfish (Crustacea: Astacoidea). Freshwat. Crayfish, 14, 221-227.

Gelder S.R., 2005. First report of Branchiobdellidans from Lake Tahoe. Crayfish New: IAA Newsletter, 27, 156-157.

Gelder S.R., 2006. Branchiobdellidans. In: Souty-Grosset C., Holdich D.M., Noël P.Y., Reynolds J.D. and Haffner P. (eds.), Atlas of Crayfish in Europe, Muséum National d'Histoire Naturelle, Paris, 148-149 (Patrimoines naturels, 64).

Gelder S.R. and Hall L.A., 1990. Description of Xironogiton victoriensis n.sp. from British Columbia, Canada, with remarks on other species and a Wagner analysis of Xironogiton (Annelida: Clitellata). Can. J. Zool., 68, 2352-2359.

Gelder S.R. and Messick G., 2006. First report of the aberrant association of branchiobdellidans (Annelida: Clitellata) on blue crabs (Crustacea: Decapoda) in the Chesapeake Bay, Maryland, USA. Invertebr. Biol., 125, 51-55.

Gelder S.R. and Ohtaka A., 2000. Redescription and designation of lectotypes of the North American Cambarincola okadai Yamaguchi, 1933 with emendations to the branchiobdellidan (Annelida: Clitellata) checklist. Proc. Biol. Soc. Wash., 113, 1087-1095.

Gelder S.R. and Smith R.C., 1987. Distribution of Branchiobdellids (Annelida: Clitellata) in Northern Maine, U.S.A. Trans. Am. microsc. Soc., 106, 85-88.

Gelder S.R., Delmastro G.B. and Ferraguti M., 1994. A report on branchiobdellidans (Annelida: Clitellata) and a taxonomic key to the species in northernItaly, including the first record of Cambarincola mesochoreus on the introduced American red swamp crayfish. Boll. Zool., 61, 179-183.

Gelder S.R., Delmastro G.B. and Rayburn J.N., 1999. Distribution of native and exotic branchiobdellidans (Annelida: Clitellata) on their respective crayfish hosts in northern Italy, with the first record of native Branchiobdella species on an exotic North American crayfish. J. Limnol., 58, 20-24.

Gelder S.R., Gagnon N.L. and Nelson K., 2002. Taxonomic considerations and distribution of the Branchiobdellida (Annelida: Clitellata) on the North American continent. Northeast. Nat., 9, 451-468.

Govedich F.R., Bain B.A., Moser W.E., Gelder S.R., Davies R.W. and Brinkhurst R.O., 2010. Annelida (Clitellata): Oligochaeta, Branchiobdellida, Hirudinida and Acanthobdellida. In: Thorp J. H. and Covich F. (eds.), Ecology and Classification of North American Freshwater Invertebrates, 3rd edn, Academic Press (Elsevier), Burlington, MA, USA, 385-436.

Henttonen P. and Huner J.V., 1999. The introduction of alien species of crayfish in Europe: a historical introduction. In: Gherardi F. and Holdich D.M. (eds.), Crayfish in Europe as Alien Species: How to Make the Best of a Bad Situation? A.A. Balkema, Rotterdam, Netherlands, 13-21.

Holdich D.M., Reynolds J.D., Souty-Grosset C. and Silby P.J. 2009. A review of the ever increasing threat to European crayfish from non-indigenous crayfish species. Knowl. Manag. Aquat. Ecosyst., 394-395, 11.
Kawai T., 2002. The introduction and current status of Procambarus clarkii in Japan. Crayfish New: IAA Newslett., $24,14-15$.

Kawai T. and Kobayashi Y., 2006. Origin and current distribution of the alien crayfish, Procambarus clarkii (Girard, 1852) in Japan. Crustaceana, 78, 1143-1149.

Kawai T. and Kobayashi Y., 2011. Crayfish Procambarus clarkii inKamakura, Kanagawa Prefecture, Japan. Nat. Hist. Rep. Kanagawa, 32, 55-62.

Kawai T., Mitamura T. and Ohtaka A., 2004. The taxonomic status of the introduced North American signal crayfish, Pacifastacus leniusculus (Dana, 1852) in Japan, and the source of specimens in the newly reported population in Fukushima Prefecture. Crustaceana, 77, 861-870.

Kirjavainen J. and Westman K., 1999. Natural history and development of the introduced signal crayfish, Pacifastacus leniusculus, in a small, isolated Finnish lake, from 1968 to 1993. Aquat. Living Resour., 12, 387-401.

Kumakawa S., Nakata K. and Kawai T., 2011. Established habitats and origin of the invasive signal crayfish Pacifastacus leniusculus in Akashina,Azumino City, Nagano Prefecture, Japan. Jpn. J. Benthol., 66, 26-32.

Laurent P.J., 2007. A French population of Pacifastacus leniusculus bears the North American parasite branchiobdellidan ectosymbiont Xironogiton victoriensis. Crayfish New: IAA Newslett., 29, 5-6.

Lewis S.D., 2002. Pacifastacus. In: Holdich D.M. (ed.), Biology of Freshwater Crayfish, Blackwell Science, London, UK, 511-540.

Liang Y.-L., 1963. Studies on the aquatic Oligochaeta of China. I. Descriptions of new naiads and branchiobdellids. Acta Zool. Sinica, 15, 560-570.

McManus L.R., 1960. Some ecological studies of the Branchiobdellidae (Ogigochaeta). Trans. Am. Microsc. Soc., 79, 420-428.

Niwa N. and Ohtaka A., 2006. Accidental introduction of symbionts with imported freshwater shrimps. In: Koike F., Clout M.N., Kawamichi M., De Poorter M. and Iwatsuki K. (eds.), Assessment and control of Biological Invasion Risks, IUCN, Cambridge, UK, 182-186.

Niwa N., Ohtomi J., Ohtaka A. and Gelder S.R., 2005. The first record of the ectosymbiotic branchiobdellidan Holtodrilus truncatus (Annelida, Clitellata) and on the freshwater shrimp Neocardina denticulata denticulata (Caridea, Atyidae) in Japan. Fish. Sci., 71, 685-687.

Oberkofler B., Quaglio F., Füreder L., Fioravanti M.L., Giannetto S., Morolli C. and Minelli G., 2002. Species of Branchiobdellidae (Annelida) on freshwater crayfish in South Tyrol (northern Italy). Bull. Fr. Pêche Piscic., 367, 777-784.

Ohtaka A., Gelder S.R., Kawai T., Saito K., Nakata K. and Nishino M., 2005. New records and distribution of two North American branchiobdellidan species (Annelida: Clitellata) from introduced signal crayfish, Pacifastacus leniusculus, in Japan. Biol. Invasions, 7, 149-156.

Ohtaka A., Gelder S.R., Nishino M., Niwa N., Ikeda M., Toyama H., Cui Y.-D., He X.-B., Wong H.-Z., Chen R.-O. and Wang S., 2012. Distributions of two ectosymbionts, branchiobdellidans (Annelida: Clitellata) and scutariellids (Platyhelminthes: "Turbellaria": Temnocephalida), on atyid shrimp (Arthropoda: Crustacea) in southeast China. J. Nat. Hist., 46, 1547-1556. 
Quaglio F., Fioravanti M.L., Gelder S.R., Giannetto S., Trentini M., Nobile L., Maxia M. and Morolli C., 2001. Infestation of the branchiobdellidan, Xironogiton victoriensis (Annelida: Clitellata), on the signal crayfish (Pacifastacus leniusculus) from Auenbachl Creek, Alto Adige/Süd Tyrol, Italy. Freshwat. Crayfish, 13, 274-279.

Riegel J.A., 1959. The systematics and distribution of crayfish in California. Calif. Fish Game, 45, 29-50.

Robinson D.A., 1954. Cambarincola gracilis sp. nov., a branchiobdellid oligochaete commensal on western crayfishes. J. Parasitol., 40, 466-469.

Subchev M.A., 2008. Branchiobdellidans (Annelida: Clitellata) found in the crayfish and annelid collections of the French National Museum of Natural History (Paris), and on recently collected crayfishes fromFrance. Acta Zool. Bulgar., 60, 233-237.

Vogt G., 1999. Diseases of European freshwater crayfish, with particular emphasis on interspecific transmission of pathogen. In: Gherardi, F. and Holdich D.M. (eds.), Crayfish in Europe as Alien Species: How to Make the Best of a Bad Situation? A.A. Balkema, Rotterdam, Netherlands, 87-103.

Westman K., 1973. The population of the crayfish, Astacus astacus L. inFinland and the introduction of the American crayfish Pacifastacus leniusculus Dana. Freshwat. Crayfish, 1, 41-55.

Yamaguchi H., 1933. Description of a new branchiobdellid, Cambarincola okadai, n. sp., parasitic on American crayfish transferred into a Japanese lake. J. Fac. Sci. Univ. Hokkaido (Zool.), 9, 191-193. 